\title{
MIXED-EFFECTS GROWTH CURVES IN THE EVALUATION OF NELLORE SIRES
}

\author{
Suely Ruiz Giolo ${ }^{1}$; Robin Henderson²; Clarice Garcia Borges Demétrio ${ }^{3 *}$ \\ ${ }^{1}$ UFPR - Depto. de Estatística, C.P. 19081 - 81531-990 - Curitiba, PR - Brasil. \\ ${ }^{2}$ Newcastle University/School of Mathematics \& Statistics - NE1 7RU - UK. \\ ${ }^{3}$ USP/ESALQ - Depto. de Ciências Exatas, C.P. 09 - 13418-900 - Piracicaba, SP - Brasil. \\ *Corresponding author <clarice@esalq.usp.br>
}

\begin{abstract}
Cattle breeding programmes need objective criteria in order to evaluate and subsequently improve production systems. This work uses a logistic growth curve model for evaluating sires based on their progeny weight measured repeatedly over time. The parameters of the curve are described as a linear function of fixed and random effects. A Bayesian approach is used for the estimation. Analysis of the weights recorded on animals of the Nellore breed shows that growth curve models with fixed and random effects can be useful to evaluate and selecting sires.

Key words: beef cattle, logistic model, longitudinal data, random effects

\section{CURVAS DE CRESCIMENTO DE EFEITOS MISTOS NA AVALIAÇÃO DE TOUROS NELORE}

\begin{abstract}
RESUMO: Programas de melhoramento de bovinos necessitam critérios objetivos para avaliar e subsequentemente melhorar o sistema de produção. Este trabalho faz uso de um modelo de curva de crescimento logístico para avaliar touros com base nos pesos de suas progênies registrados repetidamente ao longo do tempo. Os parâmetros da curva são descritos como funções lineares de efeitos fixos e aleatórios. Uma abordagem Bayesiana é considerada para a estimação dos parâmetros. Análise de dados de pesos de animais da raça Nelore mostra que os modelos de curva de crescimento com efeitos fixos e aleatórios podem ser úteis para avaliar e selecionar touros.

Palavras-chave: gado de corte, modelo logístico, dados longitudinais, efeitos aleatórios
\end{abstract}

\section{INTRODUCTION}

When considering the importance of selection in genetic breeding programs, several criteria have been proposed as measures of success. Weight measured over time (or at given ages) or gains of weight in a particular period are traits generally used for modelling growth performance of beef cattle.

To analyse growth data of beef cattle, non-linear functions such as Richard's, von Bertalanffy, Brody's, Gompertz's and Logistic growth curves, which describe the weight-age relationship, have been used with success (Fitzhugh Jr, 1976; DeNise \& Brinks, 1985; Perotto et al., 1992; Blasco et al., 2003; Freitas, 2005; Forni, 2007). Another approach is to adjust weights to standard ages and use uni- or multitrait analyses to estimate genetic parameters and to predict breeding values for weight at these ages (Kirkpatrick \& Heckman, 1989; Eler et al., 1995). A recent approach is to consider the random regression (Jamrozik \& Schaeffer, 1997; Olori et al., 1999; Meyer, 2000; Albuquerque \& Meyer, 2001) to model traits that are recorded repeatedly over time such as weight at different ages. Robert-Granié et al. (2002) extended the random regression model to a more general class of models termed heteroskedastic random regressions. This class of models assumes that all variances of random effects can be heterogeneous. In addition, linear mixed models have also been considered by Albuquerque \& Fries (1998) for modelling average daily gain of weight and the number of days to gain a specified weight from birth to weaning, in order to propose two animal selection criteria.

The aim of this work is to evaluate the breeding values of sires using a statistical model that is based on weights measured repeatedly on their progeny. This model is a version of the growth curves (Fitzhugh Jr, 1976) within a non-linear mixed-effects model framework (Pinheiro \& Bates, 2000), with allowance for correlations between repeated records and also among weights measured on progeny generated by the same sire. Associations are allowed in the model through shared random effects. Thus, instead of considering only the overall growth curve, we assume that there is a separate growth curve for each progeny. A Bayesian approach is used for the estimation and the pa- 
rameters drawn from the posterior densities are used to summarize the breeding values of the sires.

\section{MATERIALAND METHODS}

Data used of this paper belong to 6,591 progeny of 63 Nellore sires and 5,251 dams, born during springs between 1993 and 1998 in a single herd. Nellore is a Zebu breed from India that has became predominant in Brazil due to easy care and adaptability. Beef production is the main economic destination of this cattle breed in Brazil. The number of progeny per sire varied from 3 to 460 and per dam from 1 to 5. Factors recorded and considered in the statistical analysis were sex, progeny birth year, management group, and age of the dam at birth of calf, which varied from 2 to 17 years. Approximately $65 \%$ of the progeny were female. About $10 \%$ of them were born in $1993,3 \%$ in $1994,13 \%$ in $1995,28 \%$ in $1996,34 \%$ in 1997, and $12 \%$ in 1998. A total of 102 management groups were observed, i.e., groups of progeny sharing the same permanent environment (quality of pasture, climate, amongst others) from birth to weaning. The minimum and maximum numbers of progeny per group were 11 and 176, respectively. All progeny were weighted individually at six ages. The first weight was taken at birth and the last after two years (between 740 and 886 days after birth). Descriptive statistics of these weights are shown in Table 2.

The statistical model we assumed to evaluate the sires, the logistic mixed-effects growth curve (MGC) model, is based on non-linear functions and uses the progeny weights recorded at all six ages mentioned as outcome vectors. According to Pinheiro \& Bates (2000), interpretability, parsimony and validity beyond the observed range of the data are motivations for using nonlinear mixed models rather than a competitor linear model, such as a polynomial, when analysing grouped data. A non-linear model generally uses fewer parameters than a linear model and gives a more parsimonious description of the data. In the logistic MGC model, which describes the trajectory of the growth of each progeny, the weights are expressed as:

$$
W_{i}(t)=\frac{A_{i}}{\left(1+b_{i} \exp \left\{-k_{i} t\right\}\right)}+\varepsilon_{i}
$$

where $W_{i}(t)$ is the observed weight of the progeny $i$ on time $t(i=1, \ldots, n), A_{i}$ is the asymptotic weight for progeny $i$, commonly interpreted as the adult weight. The parameter $b_{i}$ is a constant of integration that adjusts for situations where $W(0)$ and/or $t_{0}$ are not zero and $k_{i}$ is a function of the ratio between maximum growth rate and mature size, commonly referred to as maturing index (Fitzhugh Jr, 1976).

Generically, a MGC model can be represented as follows:

$W_{i}(t)=f\left(A_{i}, b_{i}, k_{i}, t\right)+\varepsilon_{i}$

where $f$ is a non-linear function expressed in terms of $A_{i}, b_{i}, k_{i}$ and $t$ with $A_{i}, b_{i}$ and $k_{i}$ expressed as linear combinations of fixed and random effects. Extensions to other growth curves are straightforward as can be seen from Table 1.

Thus, calling $\mathbf{A}, \mathbf{b}$, and $\mathbf{k}$ the vectors of the growth curve parameters $A_{\vec{i}}, b_{i}$, and $k_{i}$ of all progeny, we considered $\mathbf{A}=\mathbf{X} \boldsymbol{\beta}_{\mathrm{a}}+\mathbf{S} \mathbf{z}_{\mathrm{a}}+\boldsymbol{\varepsilon}_{\mathrm{a}}, \mathbf{b}=\mathbf{X} \boldsymbol{\beta}_{\mathrm{b}}+\mathbf{S} \mathbf{z}_{\mathrm{b}}+$ $\boldsymbol{\varepsilon}_{\mathrm{b}}$ and $\mathbf{k}=\mathbf{X} \boldsymbol{\beta}_{\mathrm{k}}+\mathbf{S} \mathbf{z}_{\mathrm{k}}+\boldsymbol{\varepsilon}_{\mathrm{k}}$ where $\boldsymbol{\beta}_{\mathrm{a}}, \boldsymbol{\beta}_{\mathrm{b}}$ and $\boldsymbol{\beta}_{\mathrm{k}}$ are the fixed effects, and $\mathbf{z}_{\mathrm{a}}, \mathbf{z}_{\mathrm{b}}$ and $\mathbf{z}_{\mathrm{k}}$ are the sire random effects for the parameters of the growth curve, $\mathbf{X}$ and $\mathbf{S}$ are incidence matrices, and $\boldsymbol{\varepsilon}_{\mathrm{a}}, \boldsymbol{\varepsilon}_{\mathrm{b}}$ and $\boldsymbol{\varepsilon}_{\mathrm{k}}$ are vectors of random errors. As in a Bayesian approach prior distributions are assigned to all unknown quantities, we consider all fixed and random effects to have normal

Table 1 - Expression of the Gompertz, Richard and Brody growth curves where $A_{i}, b_{i}, k_{i}$ are the same as described previously and $m$ is a shape parameter.

\begin{tabular}{lc}
\hline Growth curves & \multicolumn{1}{c}{ MGCM } \\
\hline Gompertz & $W_{i}(t)=A_{i} \exp \left\{-b_{i} \exp \left(-k_{i} t\right)\right\}+\varepsilon_{i}$ \\
Richard & $W_{i}(t)=A_{i}\left[\left(1-b_{i} \exp \left(-k_{i} t\right)\right)\right]^{m}+\varepsilon_{i}$ \\
Brody & $W_{i}(t)=A_{i}\left[1-b_{i} \exp \left(-k_{i} t\right)\right]+\varepsilon_{i}$ \\
\hline
\end{tabular}

Table 2 - Means, standard deviations (sd), minimum, maximum and medians of the weights recorded at six ages on 6591 Nellore progeny.

\begin{tabular}{lrrrrc}
\hline Progeny age & Mean & sd & Minimum & Maximum & Median \\
\hline Days & 30.33 & 3.47 & 15 & 46 & 30 \\
\hline at birth & 88.46 & 17.07 & 43 & 171 & 86 \\
67 to 138 & 176.50 & 23.70 & 100 & 289 & 175 \\
134 to 236 & 304.50 & 38.18 & 202 & 459 & 300 \\
282 to 454 & 372.60 & 43.32 & 270 & 570 & 366 \\
380 to 672 & 435.70 & 47.18 & 346 & 646 & 427 \\
\hline 740 to 886 & & & & \\
\hline
\end{tabular}


prior distributions. For the random errors $\varepsilon_{i}$ in Model (1), for instance, we assumed $\mathrm{N}\left(0, \sigma_{e}^{2}\right)$. Also we assumed $\varepsilon_{\mathrm{ia}}, \varepsilon_{\mathrm{ib}}$ and $\varepsilon_{\mathrm{ik}}$ normal distributed with mean 0 and variance $\sigma_{a}^{2}, \sigma_{b}^{2}$ and $\sigma_{k}^{2}$, respectively. For the hyperparameters $\tau_{\mathrm{a}}, \tau_{\mathrm{b}}, \tau_{\mathrm{k}}$ and $\tau_{\mathrm{e}}$ where $\sigma_{a}^{2}=1 / \tau_{\mathrm{a}}$, $\sigma_{b}^{2}=1 / \tau_{\mathrm{b}}, \sigma_{k}^{2}=1 / \tau_{\mathrm{k}}$, and $\sigma_{e}^{2}=1 / \tau_{\mathrm{e}}$ we assumed $\mathrm{G}$ $\left(10^{-4}, 10^{-4}\right)$ where $\mathrm{G}(\alpha, \lambda)$ indicates a gamma distribution with mean $\alpha / \lambda$ and variance $\alpha / \lambda^{2}$. For all $\beta$ parameters we assumed $\mathrm{N}\left(0,10^{3}\right)$. The sire random effects were also assumed normally distributed. A program for the BUGS software (Spiegelhalter et al., 2000) was constructed to perform the analyses using the Markov Chain Monte Carlo (MCMC) method (Gilks et al., 1996). Posterior distributions of the ranks are used as a guide to help sire evaluation. To obtain the posterior mean of the parameters, a chain of 50,000 iterations was carried out after discarding the first 5,000

From Model (1) breeders can also estimate the time to reach a desired weight for each progeny $i(i=$ $1, \ldots, n)$, as for instance $190 \mathrm{~kg}$, by:

$T_{i}=\frac{\log \left(190 b_{i}\right)-\log \left(A_{i}-190\right)}{k_{i}}, A_{i}>190$

Sires with few progeny can be used in the proposed model but conclusions about them should be drawn with care.

\section{RESULTS AND DISCUSSION}

Descriptive statistics for the weights measured at six ages from birth to past-two years are presented in Table 2. Values for weight at birth varied from 15 to $46 \mathrm{~kg}$ with a mean of $30.33(\mathrm{sd}=3.47)$. For weights measured between ages 740 and 886 days (past-two years) the mean was $435.7 \mathrm{~kg}(\mathrm{sd}=47.18)$. As expected the variance of the weights increases over time.
In order to evaluate the sires we need to focus on particular parameters of the growth curves. Both $A$, the asymptotic adult weight, and $k$ the maturing index, could be considered since each has a clear biological meaning. Although negative genetic correlation is usually expected between parameters $\mathrm{A}$ and $k$ (Notter et al., 1990; Barbato, 1991; Santoro et al., 2005), positive genetic correlation has been found for Nelore, polled Nelore and Guzerá cattle when logistic, von Bertalanffy and Richards growth curves are used (Santoro et al., 2005; Forni, 2007; Forni et al., 2007). In this work we focussed attention on the parameter $A$. Sire selection based on this parameter has in mind an increasing of the overall weight (or of the growth rate) up to the age in which information are available (around 2.5 years in this work). Table 3 shows a summary of the posterior densities for some of the significant fixed effects considered in the linear function of the parameter $A$ of the growth curve. The male effect was 47.22 with $95 \%$ credible interval of (45.13; 49.13) (Table 3). Males gained weight faster than females since the estimate is positive and the interval does not include the zero value. Similarly, a second order polynomial effect was observed for the age of dam at birth of calf (the age and age ${ }^{2}$ coefficients). This means that the progeny weight gain increases until a certain age of the cow, and then decreases. The effects of progeny birth year, and management group (not shown in table) were also significant showing that both affected the progeny weight gain. The posterior mean of the sire variance was $\sigma_{s}^{2}=69.72$, which gives evidence of a substantial sire effect. A summary of the estimates of the logistic growth curve parameters $A_{\mathrm{i}}$, $b_{\mathrm{i}}$, and $k_{\mathrm{i}}(i=1, \ldots, 6591)$ is shown in Table 4. Given that for Zebu breeds the adult weight is reached between four and six years, estimates of $A_{\mathrm{i}}$ might be slightly underestimated in this study since weights are available only up to 2.5 years.

Table 3 - Means, standard deviations, medians and credible intervals of the posterior densities of some fixed effects associated with the parameter $A$ of the growth curve where age means dam age at calf birth and byear the birth year of the progeny.

\begin{tabular}{lccccc}
\hline Parameter & Posterior & Standard & & Posterior & \multicolumn{2}{c}{ Credible Interval } \\
\cline { 5 - 6 } & Mean & Deviation & Median & $2.5 \%$ & $47.5 \%$ \\
\hline$\beta_{\text {a: sex (male) }}$ & 47.22 & 0.976 & 47.23 & 45.13 & 5.693 \\
$\beta_{\text {a: age }}$ & 4.286 & 0.807 & 4.374 & 2.686 & -0.176 \\
$\beta_{\text {a: } \text { age }^{2}}$ & -0.272 & 0.048 & -0.276 & -0.355 & -2.504 \\
$\beta_{\text {a: byear (1994) }}$ & -41.72 & 20.59 & -41.62 & -82.06 & -22.57 \\
$\beta_{\text {a: byear (1995) }}$ & -36.91 & 6.90 & -37.19 & -50.22 & -16.82 \\
$\beta_{\text {a: byear (1996) }}$ & -32.26 & 6.26 & -32.61 & -44.24 & -19.96 \\
$\beta_{\text {a: byear (1997) }}$ & -32.93 & 6.17 & -33.26 & -44.52 & -26.98 \\
$\beta_{\text {a: byear (1998) }}$ & -42.99 & 6.35 & -43.04 & -55.06 & \\
\hline
\end{tabular}


Estimates of the sire effect and credible intervals are presented in Figure 1. As the sire effect was additively incorporated, high and positive values of $z_{a j}$ $(j=1, \ldots, 63)$ are desirable. Sires with few progeny (e.g. sire 28) have wider intervals. Clearly superior sires were sires 1, 5, 20, 26, 29, 37, 58, and 60 (Figure 1). From the posterior distribution of the ranks, which provide the uncertainty associated with the rank attributed to each sire, these sires presented a high probability to be classified as good performers (Figure 2). The opposite can be seen, for instance, for sires 28 , $30,31,54$ and 57 where a high probability was observed for low ranks. For these sires a poor performance would be expected from their progeny, in the sense that the progeny demands more time to gain weight. Some sires like 12, 38 and 52, presented high probabilities to be classified in intermediate ranks, so that median performance would be expected from their progeny.

For illustration purposes, two sires among the 63 in this study were chosen such that the first has a large posterior value of $z_{a}$ and the second a small posterior value of $z_{a}$. Sires $1\left(z_{a l}=11.95\right)$ and $57\left(z_{a 57}=-\right.$ 12.06) were chosen. Substituting in (2) the estimated $A_{i}$ values $(i=1, \ldots, 6591)$, obtained in the process of estimation, times, $T_{i}$, to reach $190 \mathrm{~kg}$ were estimated. Progeny from sire 1 would reach $190 \mathrm{~kg}$ faster than those from sire 57 (Table 5). Male progeny from sire 1 took a mean time of 194.9 days $(\mathrm{sd}=17.8)$ to reach $190 \mathrm{~kg}$ whereas male progeny from sire 57 took 205.6 days $(\mathrm{sd}=17.3)$. Female progeny took longer times to reach $190 \mathrm{~kg}$. Females generated by sire 1 presented a mean time of 236.6 days ( $\mathrm{sd}=19.3)$ whereas females from sire $57,244.7$ days $(\mathrm{sd}=19.1)$. Not more than 161 days for males and 195 days for females were needed for the progeny generated by sire 1 to reach $190 \mathrm{~kg}$. All male and female progeny from sire 1 took less than 237 and 285 days, respectively, to reach 190 $\mathrm{kg}$. Hence, progeny from sire 1 presented better performance than those from sire 57.

For the male and female progeny from the two sires 1 and 57 we estimated the logistic growth curves

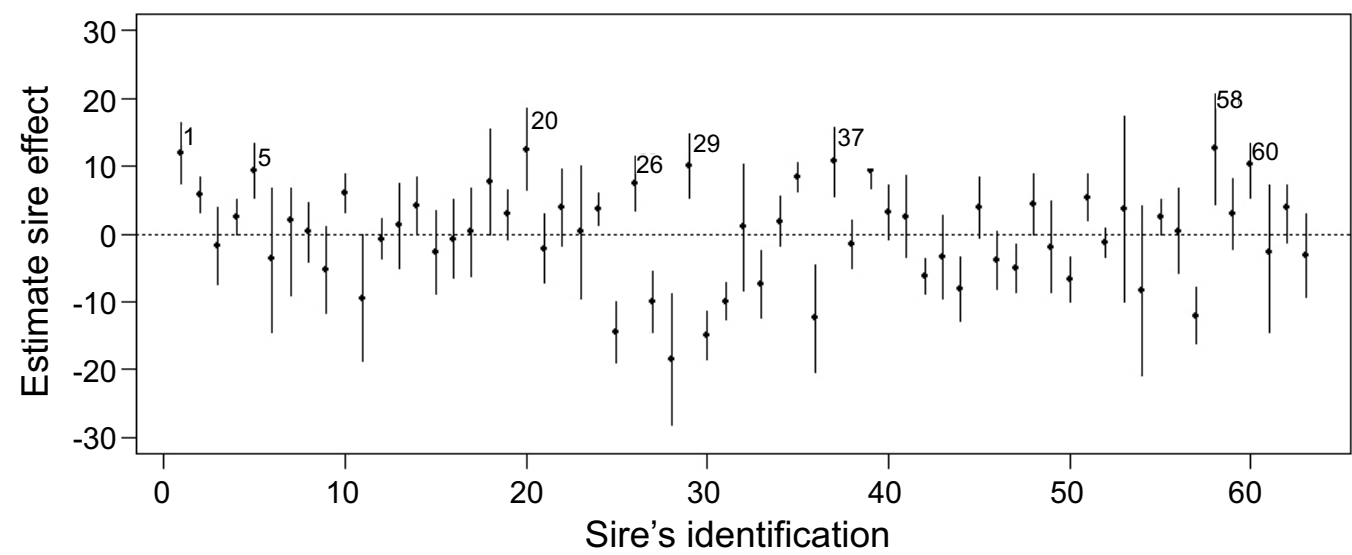

Figure 1 - Posterior means and $95 \%$ credible intervals of the $z_{a j}$ estimated sire effects associated with the parameter $A$ of the growth curve.

Table 4 - Summary of the estimates of the parameters $A_{i}, b_{i}$, and $k_{i}$ of the fitted logistic growth curves.

\begin{tabular}{|c|c|c|c|c|c|}
\hline Parameter & Minimum & Median & Mean & Maximum & Standard deviation \\
\hline$A_{i}$ & 342.4 & 418.1 & 425.3 & 635.8 & 41.80 \\
\hline$b_{i}$ & 6.64 & 8.38 & 8.42 & 13.32 & 0.64 \\
\hline$k_{i}$ & 0.0066 & 0.0086 & 0.00886 & 0.01483 & 0.0005 \\
\hline
\end{tabular}

Table 5 - Means, standard deviations (sd), minimum and maximum of the time in days estimated to reach $190 \mathrm{~kg}$ for the male and female progenies from sires 1 and 57.

\begin{tabular}{|c|c|c|c|c|c|}
\hline Sire & Progeny by sex & Mean time & sd & Minimum & Maximum \\
\hline & & -- & . & 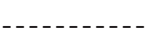 & 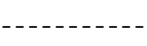 \\
\hline \multirow{2}{*}{1} & Male $(n=24)$ & 194.9 & 17.8 & 161.3 & 236.9 \\
\hline & Female $(n=32)$ & 236.5 & 19.3 & 194.7 & 284.8 \\
\hline \multirow{2}{*}{57} & Male $(n=20)$ & 205.6 & 17.3 & 178.6 & 251.3 \\
\hline & Female $(n=59)$ & 244.7 & 16.8 & 202.9 & 311.8 \\
\hline
\end{tabular}



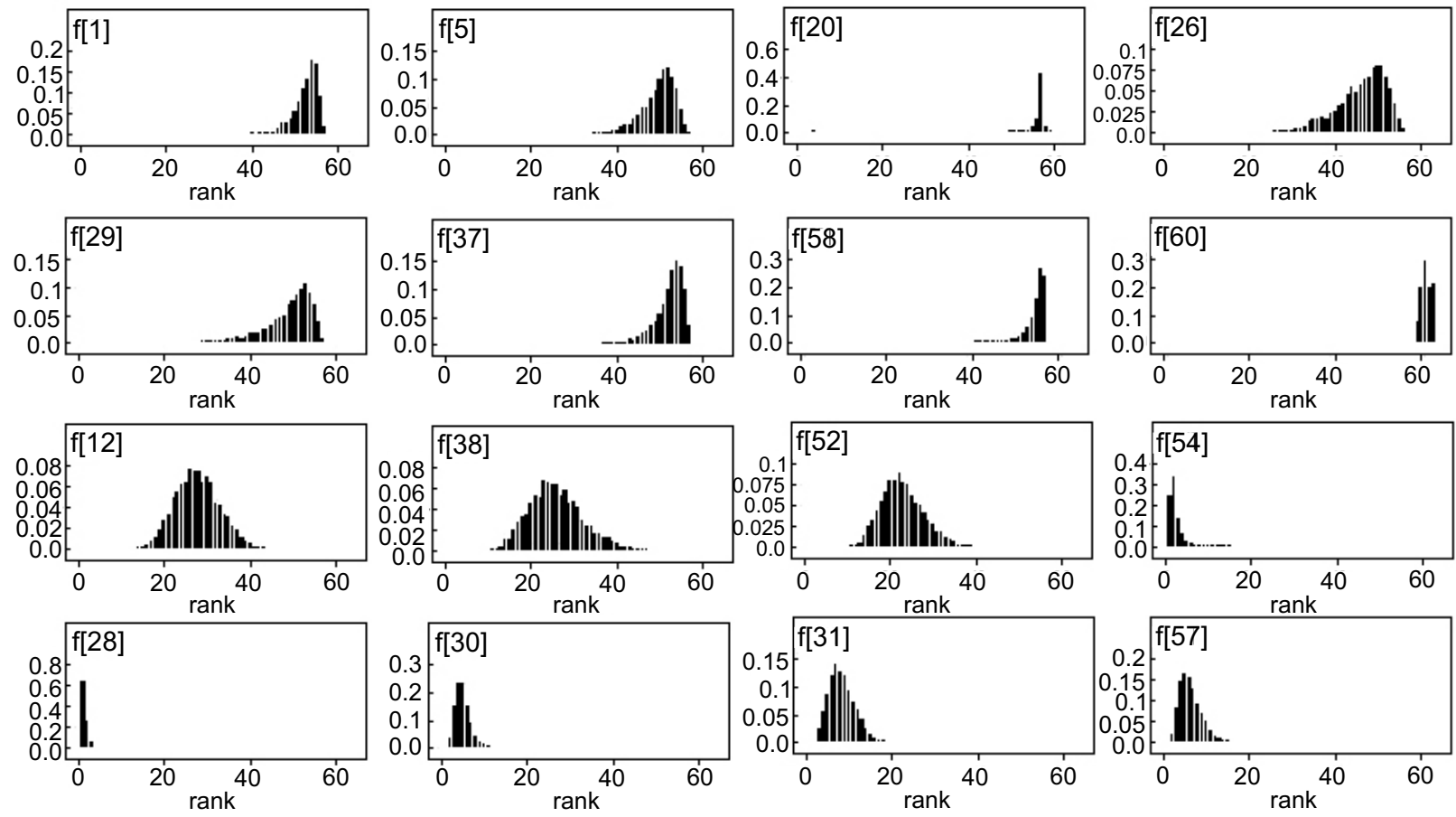

Figure 2 - Posterior distribution of the rank for some of the 63 Nellore sires under study.

Male progeny - sire 1

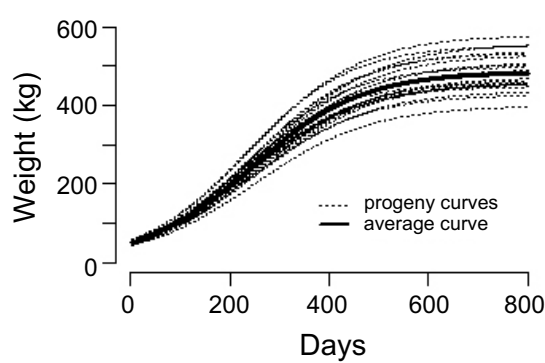

Male progeny - sire 57

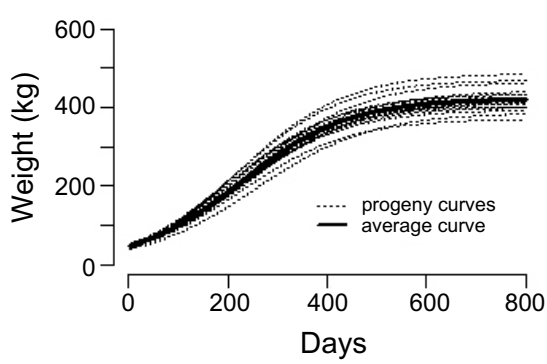

Female progeny - sire 1

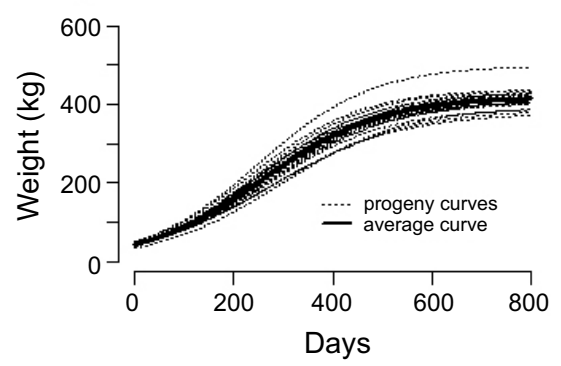

Female progeny - sire 57

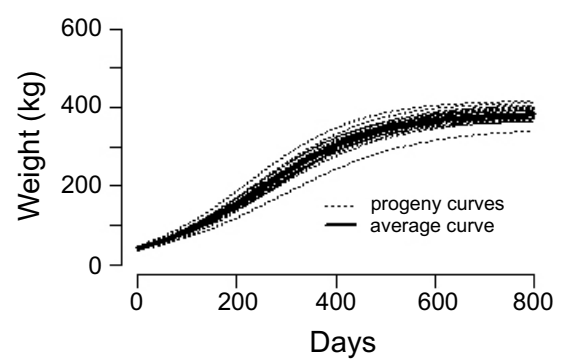

Figure 3 - Mixed logistic growth curves (---) fitted for all progeny of sire 1 (24 males and 32 females) and all progeny of sire 57 (20 males and 59 females) and associated average growth curves (-).

using the Model (1). The progeny from sire 1 presented growth rates higher than those from sire 57 (Figure 3). Comparison among progeny from a specific sire (Figure 3) can be useful not only to evaluate sires which generate progeny of high growth rate, but also to evalu- ate if the growth rates are homogeneous, i.e. if progeny from a specific sire gain weight uniformly over time. Estimates of the number of days to reach the specific weight of $190 \mathrm{~kg}$ or any other weight of interest within the observed range can be obtained (Figure 3 ). 


\section{CONCLUSIONS}

Growth curve models with fixed and random effects constitute a valuable data analysis tool for beef cattle breeding since they can be used as an additional and useful tool for selecting sires in cattle breeding programs.

\section{ACKNOWLEDGEMENTS}

We thank GenSys for providing the data CAPES for the partial financial support of the first author's $\mathrm{PhD}$ thesis, CNPq for the partial financial support to the third author.

\section{REFERENCES}

ALBUQUERQUE, L.G.; FRIES, L.A. Selection for reducing ages of marketing units in beef cattle. In: WORLD CONGRESS OF GENETIC APPLIED TO LIVESTOCK PRODUCTION, 6., Armidale, 1998. Proceedings, Armidale: University of New England, 1998. p.235-238.

ALBUQUERQUE, L.G.; MEYER, K. Estimates of covariance functions for growth from birth to 630 days of age in Nelore cattle. Journal of Animal Science, v.79, p.2776-2789, 2001.

BARBATO, G.F. Genetic architecture of growth curve parameters in chichens. Theoretical and Applied Genetics, v.83, p.2432, 1991.

BLASCO, A.; PILES, M.; VARONA, L. A Bayesian analysis of the effect of selection for growth curves in rabitts. Genetic Selection Evolution, v.35, p.21-41, 2003.

DeNISE, R.S.K.; BRINKS, J.S. Genetic and environmental aspects of the growth curve parameters in beef cattle. Journal of Animal Science, v.61, p.1431-1440, 1985.

ELER, J.P.; VLECK, L.D. van; FERRAZ, J.B.S.; LOBO, R.B. Estimation of variances due to direct and maternal effects for growth traits of Nelore cattle. Journal of Animal Science, v.73, p.3253-3258, 1995.

FITZHUGH JR, H.A. Analysis of growth curves and strategies for altering their shape. Journal of Animal Science, v.42, p.1036$1051,1976$.

FORNI, S. Análise da curva de crescimento de bovinos da raça Nelore utilizando funções não-lineares em análises Bayesianas. Jaboticabal: UNESP/FCAV, 2007. 65p. (Doutorado).
FORNI, S.; PILES, M.; BLASCO, A.; VARONA, L.; OLIVEIRA, H.N.; LÔBO, R.B.; ALBUQUERQUE, L.G. Analysis of beef cattle longitudinal data applying a non-linear model. Journal of Animal Science, v. 85, p.3189-3197, 2007.

FREITAS, A.R. Curvas de crescimento na produção animal. Revista Brasileira de Zootecnia, v.34, p.786-795, 2005.

GILKS, W.R.; RICHARDSON, S.; SPIEGELHALTER, D.J. Markov Chain Monte Carlo in practice. London: Chapman-Hall, 1996. 486p.

JAMROZIK, J.; SCHAEFFER, L.R. Estimates of genetic parameters for a test day model with random regressions for yield traits of first lactation Holsteins. Journal of Dairy Science, v. 80 , p.762-770, 1997.

KIRKPATRICK, M.; HECKMAN, N. A quantitative genetic model for growth, shape, reaction norms, and other infinitedimensional characters. Journal of Mathematical Biology, v.27, p.429-450, 1989.

MEYER, K. Random regressions to model phenotypic variation in monthly weights of Australian beef cows. Livestock Production Science, v.65, p.19-38, 2000.

NOTTER, D.R.; WYATT, W.E. Effects of genetic line and intake level on growth of mice: feed intake and mature maintenance requirements. Journal of Animal Breeding and Genetics, v.108, p.299-314, 1990.

OLORI, V.E.; HILL, W.G.; MacGUIRK, B.J.; BROTHERSTONE, $\mathrm{S}$. Estimating variance components for test day milk records by restricted maximum likelihood with a random regression animal model. Livestock Production Science, v.61, p.53-63, 1999.

PEROTTO, D.; CUE, R.I.; LEE, J. Comparison of nonlinear functions for describing the growth curve of three genotypes of dairy cattle. Canadian Journal of Animal Science, v.72, p.773-782, 1992.

PINHEIRO, J.C.; BATES, D.M. Mixed-effects models in S and S-Plus. New York: Springer, 2000. 528p.

ROBERT-GRANIÉ, C.; HEUDE, B.; FOULLEY, J.L. Modelling the growth curve of Maine-Anjou beef cattle using Heteroskedastic randon coefficients models. Genetics Selection Evolution, v.34, p.423-445, 2002.

SANTORO, K.R.; BARBOSA, S.B.P.; SANTOS, A.S.; BRASIL, L.H.A. Herdabilidades de parâmetros de curvas de crescimento não-lineares em zebuínos, no estado de Pernambuco. Revista Brasileira de Zootecnia, v.36, p.2280-2289, 2005.

SPIEGELHALTER, D.; THOMAS, A.; BEST, N. WinBUGS user manual, 2000. Available at: http://www.mrc-bsu.cam.ac.k/bugs. Accessed 4 Jul. 2007.

Received August 27, 2007

Accepted July 21, 2008 